\title{
Searching for neurological diseases in the Julio-Claudian dynasty of the Roman Empire
} À procura de doenças neurológicas na dinastia Júlio-Claudiana do Império Romano Carlos Henrique Ferreira Camargo', Hélio Afonso Ghizoni Teive²

\begin{abstract}
The gens Julia was one of the oldest families in ancient Rome, whose members reached the highest positions of power. They made history because Julius Caesar, perpetual dictator, great-uncle of the first emperor, Augustus, passed his name on to the Julio-Claudian dynasty with the emperors Tiberius, Caligula, Claudius and Nero. Descriptions of the diseases of these emperors and some of his family members may indicate diagnoses such as epilepsy, dystonia, dementia, encephalitis, neurosyphilis, peripheral neuropathies, dyslexia, migraine and sleep disorders. In the historical context of ancient Rome, the possibility of infectious diseases related to the libertine way of life is quite large. However, there is a possibility that some of these diseases occurred from genetic transmission.
\end{abstract}

Keywords: nervous system diseases; neurology; historical article; history of medicine.

\section{RESUMO}

A gens lulia era uma das mais antigas famílias da Roma Antiga, com membros que chegaram aos mais altos cargos. Ficaram na história por causa de Julius Caesar, ditador perpétuo, pai adotivo do primeiro imperador Augustus, por meio de quem seu nome passou para a dinastia Julio-Claudian com os imperadores Tiberius, Caligula, Claudius e Nero. Descrições de doenças desses imperadores e de alguns de seus familiares podem nos remeter a diagnósticos como epilepsia, distonia, demência, encefalites, neurossífilis, neuropatias periféricas, dislexia, migrânea e distúrbios do sono. No contexto histórico da Roma antiga, a possibilidade de doenças infecciosas e relacionadas ao modo de vida libertino é bastante grande. Entretanto, existe a possibilidade de que algumas dessas doenças tenham ocorrido por transmissão genética.

Palavras-chave: doenças do sistema nervoso; neurologia; artigo histórico; história da medicina.

The gens Julia (the Julii) was one of the oldest families in ancient Rome, with members who reached the highest positions of power during the first years of the Republic (Figure 1). They made history because of Julius Caesar, perpetual dictator, great-uncle and foster father of the first emperor, Augustus, through whom the name was passed to the Julio-Claudian dynasty in the first century A.D., which included the emperors Tiberius, Caligula, Claudius and Nero (Figures 1 and 2).

Some of the dramatic moments of the lives of the emperors of this family are described, mainly by Suetonius ${ }^{2.3}$ and Plutarch $^{4}$ (Table), as well as some of the attempts by their physicians to save them, or even to confirm one death, as did Antistius with Caesar.

\section{Julius Caesar}

Julius Caesar (Figure 3) was not an emperor. He was granted the title of dictator, but a possible neurological problem may have prevented him from receiving the crown. His explanation for not attending the coronation was that "his senses do not remain steady" and he was "speedily shaken and whirled about", resulting in "giddiness" and "insensibility"3. The description may represent a focal epileptic seizure with alterations of perception ${ }^{4}$. Shakespeare's ${ }^{5}$ version of this fact is much more dramatic (Chart).

Caesar had frequent headaches, and two other epileptic seizures occurred when he was young. The first was in Cordoba (Hispania); the second when he was near Thapsus, at the moment when he was arranging his army into battle formation. As soon as he felt the first symptoms, without giving the disease time to overtake him and dull his alreadyaffected senses, he made himself move to one of the towers on the outskirts and rested ${ }^{3}$. These descriptions are insufficient to claim generalized seizures, but there was certainly a focal seizure with alteration of perception ${ }^{4}$.

\footnotetext{
¿Universidade Estadual de Ponta Grossa, Hospital Universitário, Serviço de Neurologia, Ponta Grossa PR, Brasil;

${ }^{2}$ Universidade Federal do Paraná, Hospital de Clínicas, Serviço de Neurologia, Unidade de Distúrbios do Movimento, Curitiba PR, Brasil.
}

Correspondence: Carlos Henrique Ferreira Camargo; Hospital Universitário da Universidade Estadual de Ponta Grossa; Al. Nabuco de Araújo, 601; 84032-510 Ponta Grossa PR, Brasil; E-mail: chcamargo@uol.com.br 


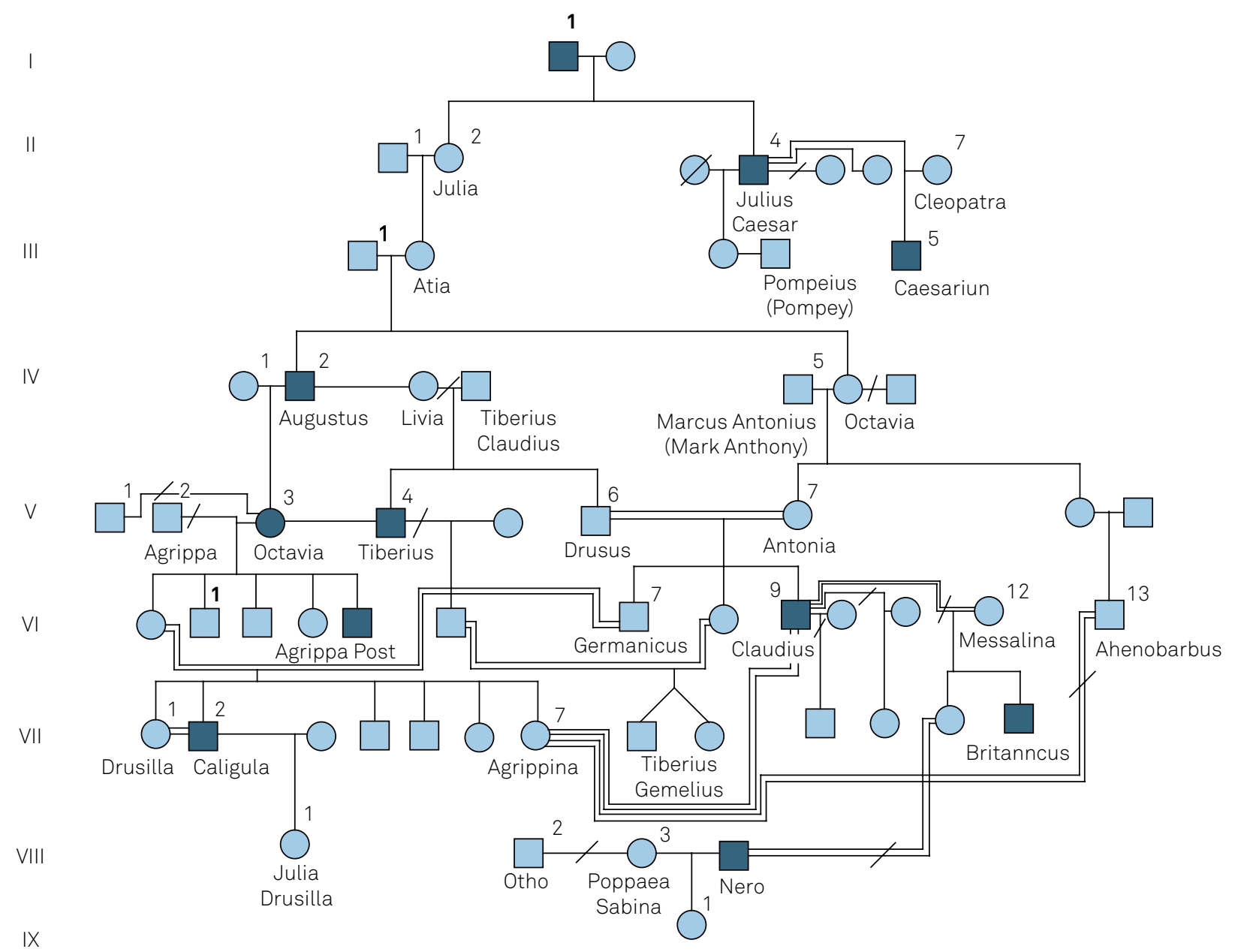

Figure 1. Pedigree of the Julio-Claudian dynasty ${ }^{1,2,3,4}$.

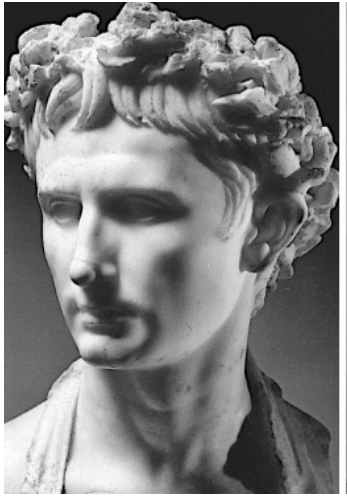

AUGUSTUS Emperor $27 \mathrm{BC}-14 \mathrm{AD}$

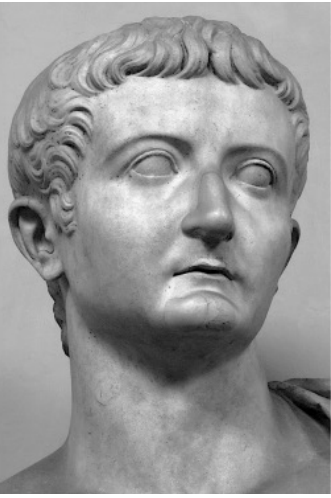

TIBERIUS

Emperor 14-37 AD

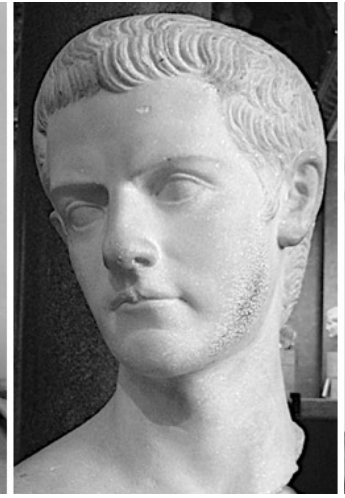

CALIGULA

Emperor 37-41 AD

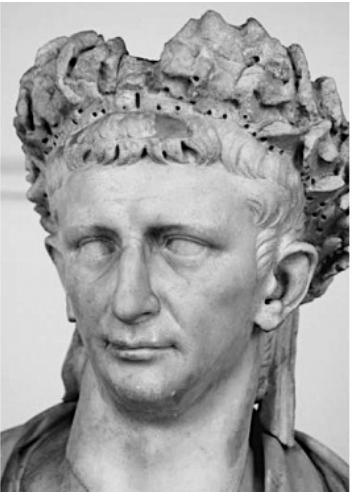

CLAUDIUS

Emperor 41-54 AD

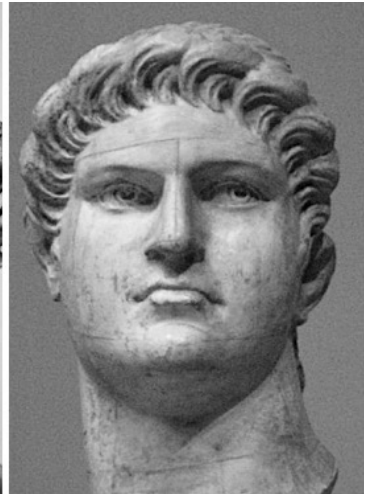

NERO

Emperor 54-68 AD

Images modified from Wikipedia (https://pt.wikipedia.org/wiki/Dinastia_júlio-claudiana).

Figure 2. Emperors of the Julio-Claudian dynasty.

The cases of epilepsy in the family opens up speculation about the possibility of sudden unexplained death in epilepsy for the sudden deaths of Caesar's father and grandfather, but there is no proof. It is possible that Caesariun, Caesar and Cleopatra's son, had his first epileptic seizure at three years of age $e^{4}$.

\section{Augustus}

Augustus, Caesar's great-nephew and heir, may have had depressive episodes during his life. It is reported that, in the course of a battle, after being defeated, Publius Varus immolated himself on his sword. Augustus' reaction was merely apathy and to let his hair and beard grow ${ }^{1}$. 
Table. Assumptions for the neurological problems of Julio-Claudian family members ${ }^{1,2,3,4}$.

\begin{tabular}{|c|c|}
\hline Julio-Claudian family & Possible neurological disorders \\
\hline \multicolumn{2}{|l|}{ Dictator } \\
\hline Julius Caesar & Epilepsy, headache (possibly migraine) \\
\hline \multicolumn{2}{|l|}{ Emperors } \\
\hline \multirow{4}{*}{ Augustus } & $\begin{array}{l}\text { Migraine, depression, insomnia, diurnal } \\
\text { somnolence (possibly epilepsy) }\end{array}$ \\
\hline & Encephalitis \\
\hline & Dyslexia \\
\hline & Peripheral neuropathies \\
\hline \multirow{4}{*}{ Tiberius } & Depression, alcoholism \\
\hline & Segmental dystonia (possibly chorea) \\
\hline & Parkinsonism \\
\hline & Dementia (alcohol, or with parkinsonism) \\
\hline \multirow{3}{*}{ Caligula } & Epilepsy \\
\hline & Insomnia \\
\hline & Encephalitis (possibly herpetic) \\
\hline Claudius & Generalized dystonia (possibly DYT6) \\
\hline Nero & Neurosyphilis \\
\hline \multicolumn{2}{|l|}{ Others } \\
\hline Gaius Caesar & Sudden unexplained death in epilepsy \\
\hline Caesariun & Epilepsy \\
\hline Octavia & Epilepsy \\
\hline Agrippa Postumus & Learning disorder (possibly ADHA) \\
\hline Brittanicus & Epilepsy \\
\hline
\end{tabular}

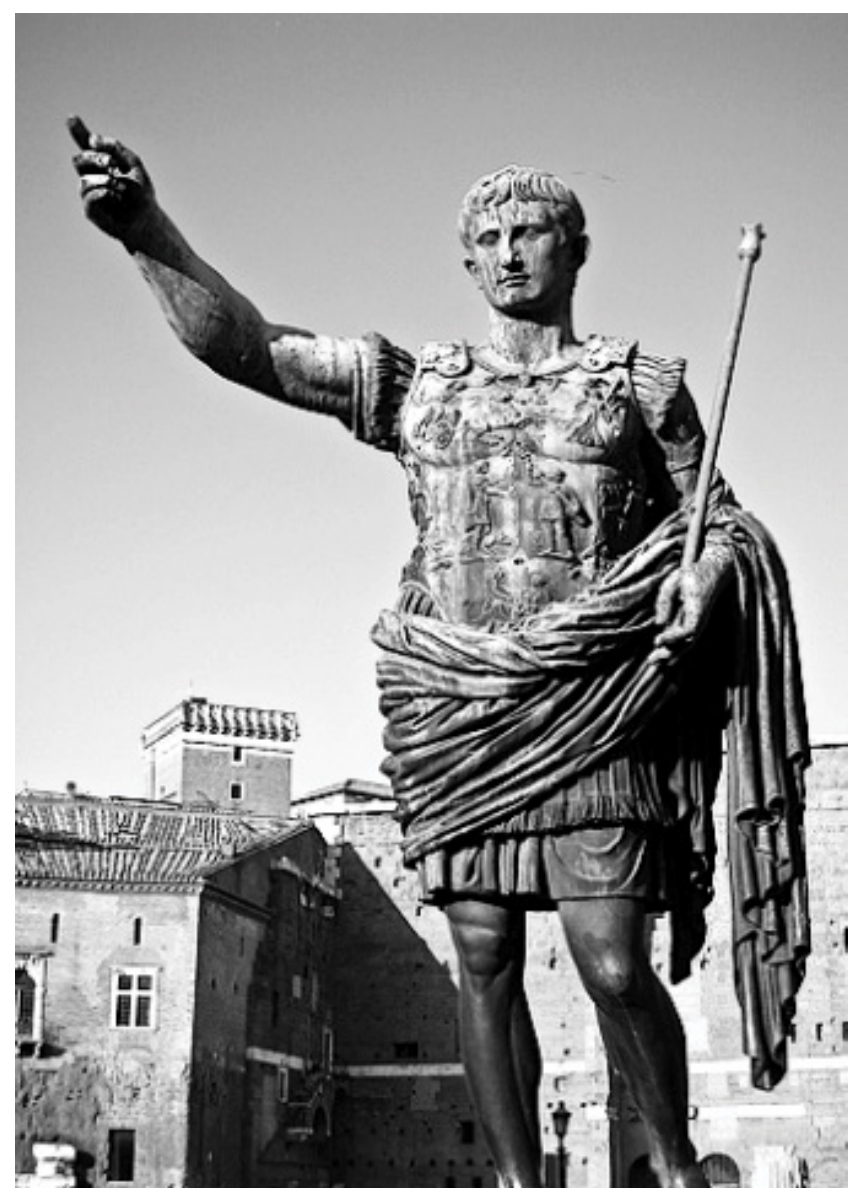

Image modified from Wikipedia (https://pt.wikipedia.org/wiki/Dinastia_júlioclaudiana).

Figure 3. Julius Caesar.

Chart. Julius Caesar by Shakespeare: epileptic seizure in the Senate ${ }^{5}$.

\begin{tabular}{|c|c|}
\hline \multicolumn{2}{|c|}{$\begin{array}{l}\text { A public place. } \\
\text { Flourish. Enter CAESAR; ANTONY, for the course; CALPURNIA, PORTIA, DECIUS BRUTUS, CICERO, BRUTUS, CASSIUS, and CASCA; } \\
\text { a great crowd following, among them a Soothsayer }\end{array}$} \\
\hline $\begin{array}{l}\text { BRUTUS } \\
\text { Tell us the manner of it, gentle Casca. } \\
\text { CASCA } \\
\text { I can as well be hanged as tell the manner of it: it was mere } \\
\text { foolery; I did not mark it. I saw Mark Antony offer him a crown; - } \\
\text { yet 'twas not a crown neither, 'twas one of these coronets; - and, } \\
\text { as I told you, he put it by once: but, for all that, to my thinking, he } \\
\text { would fain have had it. Then he offered it to him again; then he } \\
\text { put it by again: but, to my thinking, he was very loath to lay his } \\
\text { fingers off it. And then he offered it the third time; he put it the } \\
\text { third time by: and still as he refused it, the rabblement hooted } \\
\text { and clapped their chapped hands and threw up their sweaty } \\
\text { night-caps and uttered such a deal of stinking breath because } \\
\text { Caesar refused the crown that it had almost choked Caesar; for } \\
\text { he swounded and fell down at it: and for mine own part, I durst } \\
\text { not laugh, for fear of opening my lips and receiving the bad air. } \\
\text { CASSIUS } \\
\text { But, soft, I pray you: what, did Caesar swound? } \\
\text { CASCA } \\
\text { He fell down in the market-place, and foamed at mouth, } \\
\text { and was speechless. } \\
\text { BRUTUS } \\
\text { 'Tis very like: he hath the falling sickness. }\end{array}$ & $\begin{array}{l}\text { CASCA } \\
\text { Marry, before he fell down, when he perceived the common } \\
\text { herd was glad he refused the crown, he plucked me ope his } \\
\text { doublet and offered them his throat to cut. An I had been a } \\
\text { man of any occupation, if I would not have taken him at a word, } \\
\text { I would I might go to hell among the rogues. And so he fell. } \\
\text { When he came to himself again, he said, If he had done or said } \\
\text { anything amiss, he desired their worships to think it was his } \\
\text { infirmity. Three or four wenches, where I stood, cried 'Alas, good } \\
\text { soul!' and forgave him with all their hearts: but there's no heed } \\
\text { to be taken of them; if Caesar had stabbed their mothers, they } \\
\text { would have done no less. }\end{array}$ \\
\hline
\end{tabular}


With respect to spelling, Augustus' opinion was that one should write as one speaks. He used to invert or transpose not only letters, but also syllables. His grandson, Agrippa Postumus, also had a learning disorder².

Augustus would wake up three to four times a night and, when some duty woke him early, he slept while being led through the streets, or when his litter stopped for a while 2 . This daytime sleepiness may have been the result of a sleep disorder. However, considering the possibility that his sister Octavia, and other members of the clan, suffered from epilepsy, it has been hypothesized that this sleepiness could have represented some kind of epileptic seizure ${ }^{4}$.

Perpetually suffering from headaches and vomiting, he suffered his whole life from many other dangerous and serious diseases, especially after the submission of Cantabria ${ }^{2}$. Clinical signals of fever with chills and intense sweating, associated with pain in the whole body and mental confusion with delirium dominated him for several weeks ${ }^{2}$. From these signs, whose etiology is not known, it is possible to make hypotheses about encephalitis, neurological features of sepsis, or even malaria. A statue of his doctor, Antonius Musa, was erected, on the feet of Aesculapius, for having cured him of these diseases ${ }^{1,2}$.

After an illness at a young age, Augustus developed a weak hip, thigh and left leg, and walked with a limping gait. His right-hand index finger was so weak that cold weather made it numb and contracted it, and he was able to write only by using a ring of horn ${ }^{2}$. There is no information to determine if it these were symptoms of peripheral neuropathies or sequelae of encephalitis or other diseases that he could have had during his life.

\section{Tiberius}

Augustus' adoptive son, Tiberius' left hand was stronger and more skillful than the right one. When he walked, he kept his neck rigid and tilted backwards, with a certain melancholy air, and was almost always silent. He spoke slowly, with a particular repetitive gesture with his fingers. Aside from this, he was in excellent health, and did not like help and advice from doctors; he would rather consult astrology ${ }^{2}$. His neck seems to have had a dystonia, retrocollis or torticollis, which may have been accompanied by dystonia of the right upper limb, as well as dystonia and/or hand chorea. The speech problem may have been a dysarthria or a dystonia of the larynx. One could also consider a parkinsonism associated with the movements of the hands, the melancholic air and slow speech ${ }^{6}$.

For his last 11 years, Tiberius lived on the island of Capri, indulging his carnal desires. He returned twice to the continent, but did not want to go to Rome for fear of meeting people. He died at 78 years of age, disturbed by macabre hallucinations, and trying to conceal his state under a mask of artificial joy. He shifted between this agitated state with alteration periods and loss of consciousness ${ }^{1}$.
As he was an alcoholic and lived in depravity and on an uncontrolled diet, it is possible to consider causes such as Wernicke's encephalopathy, or a vascular disorder or syphilis as an etiology for dementia. The depressive symptoms, with movement disorders resulting in hallucinations and a "mask of artificial joy" may suggest a dementia with parkinsonism, as found in dementia with Lewy bodies?

\section{Caligula}

Caligula, great-nephew and heir of Tiberius, was a victim of epileptic seizures from childhood. In his youth, he could not endure hardship without being affected by sudden fainting spells that required much sacrifice to enable him to walk, keep upright, take a deep breath and sustain himself. He was tortured by insomnia, as he did not sleep more than three hours per night ${ }^{2}$.

When Caligula came into power, he wanted to erase the painful memories of the sad reign of Tiberius ${ }^{1}$. However, after seven months in power, Caligula became seriously ill ${ }^{1,2}$. After recovering, the people from Rome found a much worse version of Caligula ${ }^{1}$. He tortured and murdered senators and Roman citizens, closed the stores and declared famine in the Empire; he wished for plagues, epidemics and earthquakes to arise, collected unfair high taxes, and wanted to govern, not only as a god, but as a super-god: Oderint dum metuant (let them hate, as long as they fear $)^{1}$. At one feast, he was attacked abruptly by a crisis of intense laughter².

Although it is possible that Caligula had syphilis ${ }^{8}$, the symptoms seem to compare more with an encephalitis, with a behavioral disorder from temporal lobe epilepsy. The clinical signs may have aggravated the epileptic seizures that he had since childhood ${ }^{4}$. A herpetic encephalitis may also be a possible etiology for the event ${ }^{9}$.

\section{Claudius}

Throughout almost all his childhood and adolescence, Caligula's nephew and Julius Caesar's great-great grandnephew, Claudius, suffered from various long-term diseases, which weakened him in such a way that he was considered unfit for any public function ${ }^{2}$. Antonia, his mother, stated that he was nothing but an "abortion that nature had begun to form, but never ended"1,2.

Claudius' clinical signs were more prominent in adulthood, with changes of gait (clumsy walking and stumbling), continuous head shaking with alterations of movements and hypertrophy of the cervical muscles, involuntary movements of the limbs and face, that got worse with minimum effort and when he presented himself in public, as well as having welldelineated muscles of the body, dysarthria and dysphonia ${ }^{1,2}$. This description seems to point to a generalized dystonia and its peculiar characteristics, with the onset at the transition of childhood to adolescence. Remembering Tiberius' clinical signs of a possible segmental dystonia, with cervical spine predominance, as well as dysphonia, one could postulate the 
possibility of a dystonia type DYT6, with reduced penetrance, in this family ${ }^{6}$.

Claudius' son, Britannicus, the fruit of his relationship with his cousin Messalina, had epileptic seizures, probably a generalized primary epilepsy, between six and 13 years of age $e^{2,410}$.

\section{Nero}

Despite his life of orgies, Nero, Augustus' great great grandson and adopted son of Claudius, had only been seriously ill about three times during his reign. Nero had a fetid odor; his body was covered in pustules and suspicious skin spots. His nape was thick and the belly prominent. Thin legs supported a heavy torso ${ }^{1}$.

The first five years of Nero's reign were the five most joyful experienced by Rome. However, Nero became tyrannical, and developed delirious pretensions of being an artist, poet, actor, musician and religious worshiper. In the last years of his life he lost all sense of right and wrong. He isolated himself, and had countless wishes to kill himself. At age 32, in an advanced state of dementia, he stabbed a dagger into his throat ${ }^{1,2}$.
Nero's described skin changes may be seen in patients with severe cases of syphilis, typically associated with malnutrition and alcohol consumption leading to a decrease in immunity ${ }^{9}$. The neurological signs are also compatible with neurosyphilis, which begins insidiously with behavioral disorders and cognitive signs such as irritability, inattention, emotional lability and delirium. It evolves into dementia, tremors, dysarthria, and epileptic seizures until there is motor loss with fecal and urinary incontinence ${ }^{8}$.

\section{FINAL CONSIDERATIONS}

Despite there being few reports, it is possible to make a series of hypotheses about the neurological diseases that affected the Julio-Claudian dynasty. The possibility of symptoms of infection as the etiology is quite prominent in the historical context. However, the consanguineous marriages, and the characteristics of dystonia and the epilepsies, may open the possibility of a discussion of genetic diseases in the emperors and their families.

\section{References}

1. Lissner, I. Os Césares: apogeu e loucura. Belo Horizonte: Itatiaia; 1985.

2. Suetônio. A vida dos doze Césares. São Paulo: Martin Claret; 2004. (Coleção A obra prima de cada autor. Série Ouro).

3. Plutarco. Vidas paralelas: Alexandre e César. Porto Alegre: L\&PM; 2005

4. Hughes JR. Dictator Perpetuus: Julius Caesar: did he have seizures? If so, what was the etiology? Epilepsy Behav. 2004:5(5);756-64. https://doi.org/10.1016/j.yebeh.2004.05.006

5. Shakespeare W. Julius Caesar. New York: Washington Square; 1958.

6. Camargo CH, Camargos ST, Cardoso FE, Teive HA. The genetics of the dystonias--a review based on the new classification of the dystonias. Arq Neuropsiquiatr. 2015;73(4):350-8. https://doi.org/10.1590/0004-282X20150030
7. Gomperts SN. Lewy body dementias: dementia with Lewy Bodies and Parkinson disease dementia. Continuum (Minneap Minn). 2016;22(2 Dementia):435-63. https://doi.org/10.1212/CON.0000000000000309

8. Conde-Sendín MA, Hernández-Fleta JL, Cárdenes-Santana MA, Amela-Peris R. Neurosyphilis: forms of presentation and clinical management. Rev Neurol. 2002;35(4):380-6. Spanish.

9. Li JH, Guo H, Zheng S, Li B, Gao XH, Chen HD. Widespread crusted skin ulcerations in a man with type II diabetes: a quiz. Acta Derm Venereol. 2015;95(5):632-3. https://doi.org/10.2340/00015555-1999

10. Michael BD, Solomon T. Seizures and encephalitis: clinical features, management, and potential pathophysiologic mechanisms. Epilepsia. 2012;53 Suppl 4:63-71. https://doi.org/10.1111/j.1528-1167.2012.03615.x 